\title{
ХАРАКТЕРИСТИКА ПОНЯТТЯ «ПРАВОВА КУЛЬТУРА» ЧЕРЕЗ ПРИЗМУ МЕТОДОЛОГІЧНИХ ПІДХОДІВ
}

\author{
Підлісний $\boldsymbol{C}$. В., здобувач \\ Україна, Умань, Уманський державний педагогічний університет імені Павла Тичини
}

DOI: https://doi.org/ 10.31435/rsglobal_ws/31102018/6183

\begin{tabular}{|c|c|}
\hline ARTICLE INFO & ABSTRACT \\
\hline $\begin{array}{l}\text { Received: } 05 \text { August } 2018 \\
\text { Accepted: } 10 \text { October } 2018 \\
\text { Published: } 31 \text { October } 2018\end{array}$ & \multirow{3}{*}{$\begin{array}{l}\text { The article attempts to classify the interpretation of the concept of "legal } \\
\text { culture" through the axiological, competence, activity and complex } \\
\text { approaches. It is established that from the standpoint of the axiological } \\
\text { approach, scholars consider the legal culture as a qualitative level of } \\
\text { legal reality at a particular stage of development of society, competence - } \\
\text { through legal competence, activity as a type and way of activity, way of } \\
\text { thinking, norms and standards of behavior, a specific way of organizing } \\
\text { and developing human activity in the field of legal relations, complex - } \\
\text { the legal culture is connected with the political, moral, aesthetic, } \\
\text { economic culture and its other varieties. It is proved that in the } \\
\text { interpretation of the legal culture there are serious differences: some } \\
\text { authors in the definition of culture determine through the activity and in } \\
\text { this regard consider the legal culture as an element of the culture of a } \\
\text { wider system; others are regarded as an independent sphere, where the } \\
\text { legal culture is its part. }\end{array}$} \\
\hline & \\
\hline $\begin{array}{l}\text { legal cultura, } \\
\text { axiological approach, } \\
\text { competency approach, } \\
\text { activity approach, } \\
\text { complex approach. }\end{array}$ & \\
\hline
\end{tabular}

Citation: Підлісний Є. В. (2018) Kharakterystyka Poniattia «Pravova Kultura» Cherez Pryzmu Metodolohichnykh Pidkhodiv. World Science. 10(38), Vol.2. doi: 10.31435/rsglobal_ws/31102018/6183

Copyright: (C) 2018 Підлісний С. В. This is an open-access article distributed under the terms of the Creative Commons Attribution License (CC BY). The use, distribution or reproduction in other forums is permitted, provided the original author(s) or licensor are credited and that the original publication in this journal is cited, in accordance with accepted academic practice. No use, distribution or reproduction is permitted which does not comply with these terms.

Вступ. Сучасна освіта взаємопов'язана зі змінами соціальної структури суспільства, новими тенденціями в розвитку права і законодавства, в здійсненні правової підготовки громадян. Тільки в ході організованої, цілеспрямованої і керованої правової освіти, органічно утворюється цілісний правоосвітній процес із застосуванням системи спеціальних форм і засобів, за яких можливе ефективне формування правової культури як окремих індивідів, так і соціальних груп.

Правова культура $є$ важливим елементом (складником) загальної культури особистості. Вона формується як органічний синтез змістовних ліній, що охоплюють сутнісні характеристики особистості. У широкому розумінні вона $є$ системою матеріальних і духовних цінностей у сфері функціонування права [9, с.3].

Правова культура - надзвичайно ємне явище. Ї̈̈ суспільна значущість багато в чому перевершує межі нормативного впливу права на соціальні відносини, оскільки, будучи складовою частиною загальнолюдської культури, правова культура прямо і побіжно впливає на формування свідомості і діяльність особистості в найрізноманітніших сферах життя суспільства. Тому не випадково, що до переважної більшості проблем побудови правової держави і громадянського суспільства питання формування правової культури мають пряме відношення.

У науковій літературі недостатньо розроблені методологічні підходи визначення правової культури. Ця тема міцно утвердилася в навчальних посібниках 3 теорії держави і права (А. Берлач, А. Венгеров, Н. Головко, С. Жилінський, О. Коломієць, В. Копєйчиков, В. Лемак, М. Марченко, В. Молдаван, А. Олійник, В. Ординський, О. Петришин, В. Пічі, П. Рабінович, С. Тимченко, В. Суботін, Н. Фоменко, М. Цвік). У трактуванні правової культури 
мають місце серйозні розбіжності. Одні автори у визначенні культури виходять 3 діяльності і в цьому плані розглядають правову культуру як елемент культури більш широкої системи. Інші розглядають як самостійну сферу, де правова культура $є$ іiі частиною. Крім того, базові поняття «культура» і «право» також трактуються по-різному.

Результати дослідження. У науковій літературі немає єдиної думки щодо поняття «правова культура». Проте, у результаті всебічного аналізу цього правового явища варто виокремити аксіологічний, компетентнісний, діяльнісний та комплексний підходи дослідження правової культури.

До прихильників аксіологічного підходу у визначенні правової культури, які розглядають іï через призму правових цінностей можна віднести I. Кравченко [5], В. Лемака [7], К. Лінейцеву [8], А. Халтуріна [15], та ін. Трактування ними правової культури показано у таблиці 1.

Таблиця 1. Характеристика поняття «правова культура» за аксіологічним підходом

\begin{tabular}{|c|c|}
\hline К. Лінейцева & $\begin{array}{l}\text { Правова культура - це, перш за все, система цінностей і норм, закорінених } \\
\text { у свідомості і мотивації, що обумовлюють поведінку індивіда i } \\
\text { виражаються в традиціях, стилі взаємин між особистістю і правом. } \\
\text { Правова культура включає такі елементи, як культура правової свідомості, } \\
\text { культура правових відносин, культура правової діяльності, тобто } \\
\text { законність, правопорядок, законотворчу, правозастосовчу і інші види } \\
\text { діяльності в сфері функціонування права }\end{array}$ \\
\hline В. Лемак & $\begin{array}{l}\text { Правова культура за своїм змістом є певним юридичним багатством, яке } \\
\text { виражається в досягнутому рівні регулятивних властивостей права, } \\
\text { нагромаджених правових цінностей, тих особливостей права, юридичної } \\
\text { техніки, котрі належать до духовної культури, до правового прогресу }\end{array}$ \\
\hline В. Сальников & $\begin{array}{l}\text { Правова культура - одна з категорій загальнолюдських цінностей, найважливіший } \\
\text { результат загальнодемократичних завоювань прогресивного людства }\end{array}$ \\
\hline Н Годун & $\begin{array}{l}\text { Правова культура - різновид загальної культури, який становить систему } \\
\text { цінностей, досягнутих людством у галузі права, і стосується правової } \\
\text { реальності даного суспільства. Система цінностей - це активність } \\
\text { суб'єктів права у правовій сфері, добровільність виконання вимог } \\
\text { правових норм, реальність прав і свобод громадян, ефективність правового } \\
\text { регулювання, якісні закони, досконала законодавча техніка, розвинута } \\
\text { правова наука, юридична освіта, ефективна юридична практика, } \\
\text { стабільний правопорядок }\end{array}$ \\
\hline Т. Ярошевська & $\begin{array}{l}\text { Правова культура - це така система правових цінностей, які відображають } \\
\text { у правовій формі стан свободи людини і громадянина. Це глибокі знання і } \\
\text { розуміння права, ретельне виконання його вимог як усвідомленої } \\
\text { необхідності, так і внутрішньої переконаності }\end{array}$ \\
\hline О. Ганзенко & $\begin{array}{l}\text { Правова культура - система правових цінностей, що відповідають рівню } \\
\text { досягнутого людством правового прогресу, відображають у правовій формі } \\
\text { стан свободи особи і соціальної справедливості, інші найважливіші } \\
\text { соціальні цінності у діалектичному впливі на якісний стан і спосіб } \\
\text { правового життя особи й суспільства, в якому найвищою цінністю } \\
\text { реалізація прав і свобод людини та їх захист }\end{array}$ \\
\hline Н. Фоменко & $\begin{array}{l}\text { Правова культура - одна із загальнолюдських цінностей, складне } \\
\text { утворення загальнодемократичних, загальнокультурних надбань } \\
\text { прогресивного людства, коли вона стає невід'ємним компонентом } \\
\text { цивілізованої і правової держави, яка визначає у своїй організації та } \\
\text { діяльності право, підпорядковане цивільному суспільству, гарантуючи } \\
\text { невідчужені права кожної людини }\end{array}$ \\
\hline В. Копєйчиков & $\begin{array}{l}\text { Правова культура - це система правових цінностей, що відповідають } \\
\text { рівню досягнутого суспільством правового прогресу і відображають у } \\
\text { правовій формі стан свободи особи, інші найважливіші соціальні цінності }\end{array}$ \\
\hline $\begin{array}{l}\text { Великий } \\
\text { юридичний } \\
\text { словник }\end{array}$ & $\begin{array}{l}\text { Правова культура - система цінностей, правових ідей, переконань, } \\
\text { навичок і стереотипів поведінки, правових традицій, прийнятих членами } \\
\text { певної спільноти (державної, релігійної, етнічної), що використовуютья } \\
\text { для врегулювання їх діяльності }\end{array}$ \\
\hline
\end{tabular}


Продовження таблиці 1

\begin{tabular}{|l|l|}
\hline $\begin{array}{l}\text { Юридична } \\
\text { енциклопедія }\end{array}$ & $\begin{array}{l}\text { Правова культура - це система духовних і матеріальних цінностей у сфері } \\
\text { функціонування права; є складовою загальної культури, охоплює всю } \\
\text { сукупність найважливіших ціннісних компонентів правової реальності в її } \\
\text { розвитку (право, правосвідоміст, правовідносини, правопорядок, } \\
\text { нормотворча, правозастосовча та інша правова діяльність), виступає } \\
\text { однією 3 категорій загальнолюдських цінностей, є невід’ємним } \\
\text { компонентом правової держави }\end{array}$ \\
\hline А. Семітко & $\begin{array}{l}\text { Правова культура передбачає оцінку «якості» правового життя того чи } \\
\text { іншого суспільства та порівняння ії } 3 \text { найрозвинутішими правовими } \\
\text { зразками, ідеалами та цінностями }\end{array}$ \\
\hline О. Комарова & $\begin{array}{l}\text { Правова культура - це система, правових цінностей, які створююються в ході } \\
\text { розвитку суспільства і концентрує в собі досягнення юридичної культури }\end{array}$ \\
\hline
\end{tabular}

Отже, з позицій аксіологічного підходу науковці розглядають правову культуру як якісний рівень правової дійсності на конкретному етапі розвитку суспільства. Під правовою культурою вони розуміють якісний стан правового життя суспільства, який проявляється в досягнутому рівні досконалості правових актів, правової і правозастосовчої діяльності, правосвідомості і правового розвитку особистості, а також ступеня свободи іiі поведінки і взаємної відповідальності держави і особистості, позитивно впливають на суспільний розвиток і підтримку самих умов існування суспільства.

Цей погляд найбільш точно виражає аксіологічну сутність правової культури суспільства. Поділяючи цю точку зору, підкреслимо, що правову культуру слід розуміти як розвивальну систему правових цінностей (правосвідомість, правова наука, законодавство, правопорядок, правова діяльність), створених і створюваних в ході розвитку суспільства, які увібрали в себе передові досягнення перш за все юридичної культури людства. Такий підхід забезпечує характеристику правової культури як спосіб гуманізації людини і суспільства, він дозволяє чітко відмежувати правову культуру від інших близьких і взаємопов'язаних з нею правових категорій, обгрунтувати іiі наступність і підкреслює, що до неї відносяться лише процеси і явища, які відображають сутність правової держави і громадянського суспільства, його основні засади і принципи. Необхідно відзначити, що аксіологічний підхід в дослідженні правової культури грунтується на філософському вивченні саме ціннісного аспекту культури i дає можливість визначити соціальні основи правової культури, об'єктивні властивості ії нормативності, духовні та моральні аспекти. В даному підході дійсно простежується зв'язок правової культури і моральності членів суспільства, без якої правова культура неможлива.

У рамках компетентнісного підходу науковці (С. Аграновська [1], Р. Андрусишин [2], I. Галущак [3], I. Огороднійчук [11]) розглядають правову культуру через правову компетентність, визначення якої подано у таблиці 2.

Таблиця 2. Характеристика поняття «правова культура» за компетентнісним підходом

\begin{tabular}{|l|l|}
\hline С. Аграновська & $\begin{array}{l}\text { Правова компетентність виникає, розвиваєтья і перетворюється за } \\
\text { допомогою діяльності, розуміється як синонім діяльності, як специфічний } \\
\text { спосіб людської активності }\end{array}$ \\
\hline Н. Ржевська & $\begin{array}{l}\text { Правова компетентність виступає в ролі фундатора при формуванні інших } \\
\text { компетентностей, правового мислення, правової свідомості, правової } \\
\text { культури, правової поведінки, правового менталітету, і в певній мірі } \\
\text { Ідатна визначати професійний життєвий успіх }\end{array}$ \\
\hline І. Галущак & $\begin{array}{l}\text { Правова компетентність - це система правових знань, переконань, } \\
\text { навичок, досвіду, механізму дії права і правових технологій, що } \\
\text { дозволяють особистості орієнтуватись у правовому полі, юридично } \\
\text { грамотно знаходити в ньому вирішення завдань, які виникають. } \\
\text { Правова компетентність майбутнього економіста розуміється як } \\
\text { особистісно-професійна якість, що виявляється у здатності до пізнання } \\
\text { соціально-правової дійсності, усвідомленні ціннісного впливу права на } \\
\text { клієнтів, спроможності відповідально здійснювати правозахисну і право } \\
\text { реалізаційну діяльність }\end{array}$ \\
\hline
\end{tabular}


Продовження таблиці 2

\begin{tabular}{|l|l|}
\hline Р. Андрусишин & $\begin{array}{l}\text { Професійна компетентність майбутнього економіста - сформована } \\
\text { система професійних знань, умінь, навичок, способів діяльності, } \\
\text { здібностей, ціннісних орієнтацій, стилю спілкування, необхідних для його } \\
\text { якісної діяльності в галузі економіки та фінансів }\end{array}$ \\
\hline Н. Розіна & $\begin{array}{l}\text { Соціально-правова компетентність - інтегративна якість особистості } \\
\text { майбутніх кваліфікованих робітників, що охоплює систему соціально- } \\
\text { правових знань і вмінь, конструктивні соціальні установки, досвід } \\
\text { правової соціалізації, професійно важливі якості, необхідні для } \\
\text { здійснення професійної діяльності та соціальної взаємодії }\end{array}$ \\
\hline
\end{tabular}

Аналіз правової культури через правову компетентність показує, що вона $є$ ознакою правової культури. Компетентна людина - це особистість високого рівня правової культури з почуттями, переживаннями, емоціями, намаганнями, спрямованими на утвердження правопорядку, звільнення, усунення із суспільного життя протизаконних фактів, досягнення грамотності і кваліфікованості як цінності. Зазначимо, що між правовою культурою та правовою компетентністю існує діалектичний зв'язок, оскільки відсутність правової культури робить неможливим розвиток правової компетентності; а правова культура є основою для правової компетентності.

Прихильниками діяльнісного підходу до визначення правової культури, який указує на різні аспекти та характеристики людської діяльності є А. Курносенко [6], А. Халтурін [15], С. Циганій [16], С. Чернета [17]. Науковці правову культуру розуміють як специфічний засіб людського буття у сфері права, створений людьми метод соціального управління, який полягає в цілеспрямованому впливові на поведінку індивідів 3 метою досягнення порядку й стабільності в суспільстві.

Правова діяльність спрямована на підпорядкування вчинків, дій, поведінки громадських суб'єктів нормам, які відображають соціальну природу права, закономірності його структури, існування. Правова діяльність, що $є$ сутністю правовідносин, як структурного елементу правової культури суспільства, як і вся людська діяльність, не тільки стимулюється i координується, а й відтворюється через накопичення правового досвіду шляхом прояву його у відповідних групових стереотипах діяльності і передачі їх з покоління в покоління [4, с. 147].

Характеристика поняття «правова культура» за діяльнісним підходом подана у таблиці 3.

Таблиця 3. Характеристика поняття «правова культура» за діяльнісним підходом

\begin{tabular}{|c|c|}
\hline I. Шаравара & $\begin{array}{l}\text { Правова культура - зумовлений соціально-економічним та політичним } \\
\text { устроєм стан правового життя суспільства, що відображається в } \\
\text { досягнутому рівні розвитку законодавчої техніки, правовій діяльності та } \\
\text { правосвідомості суб'єктів }\end{array}$ \\
\hline С. Чернета & $\begin{array}{l}\text { Правова культура - цілеспрямована, систематична діяльність органів та } \\
\text { соціальних інститутів, що передбачає озброєння вихованця соціально- } \\
\text { правовими просвітницькими знаннями, перетворення цих знань в } \\
\text { особисті переконання людини та формування на цій основі } \\
\text { відповідального ставлення до власних вчинків, до поведінки в цілому }\end{array}$ \\
\hline С. Циганій & $\begin{array}{l}\text { Правова культура є сукупністю знань, умінь і навичок застосування їх на } \\
\text { практиці, сприяє забезпеченню законності в суспільстві }\end{array}$ \\
\hline А. Халтурін & $\begin{array}{l}\text { Правова культура - це правова інформація, яка накопичується, } \\
\text { зберігається і передається в суспільстві за допомогою створюваних } \\
\text { людьми знакових систем. у правовій культурі автори виділяють } \\
\text { «культуру поведінки» і «культуру законодавства» }\end{array}$ \\
\hline A. Кур & $\begin{array}{l}\text { Правова культура являє собою складний комплекс явищ суспільного } \\
\text { життя, що включає правові норми, принципи, правосвідомість, } \\
\text { правовідносини, правову поведінку в процесі реалізації життєвих } \\
\text { установок }\end{array}$ \\
\hline Н. Годун & $\begin{array}{l}\text { Правова культура - це обумовлений усім соціальним, духовним, } \\
\text { політичним та економічним розвитком якісний стан правового життя } \\
\text { суспільства, що виражається в досягнутому рівні розвитку правової } \\
\text { діяльності, юридичних законів, правосвідомості, правового розвитку } \\
\text { суб'єкта (людини, різних груп, усього населення), а також ступеня } \\
\text { гарантованості державою і громадянським суспільством прав і свобод } \\
\text { людини }\end{array}$ \\
\hline
\end{tabular}


Аналіз літератури показує, що представники діяльнісного підходу дотримуються точки зору, згідно з якою правова культура визначається як вид і спосіб діяльності, спосіб мислення, норми i стандарти поведінки, специфічний спосіб організації і розвитку людської життєдіяльності в сфері правових відносин, якісний стан правового життя суспільства, виражений в рівні правосвідомості, вдосконаленні правових актів та юридичної практики і в інших правових цінностях.

Комплексний підхід робить можливим розгляд правової культури через призму загальної культури (С. Мальона [10], В. Потомахін [12], Р. Сербин [13], О. Скакун [14]). Загальне поняття правової культури здійснене на основі комплексного підходу с. Мальоною інтегровано через поняття «правова культура особистості», де враховували ряд важливих моментів: правова культура особистості може бути представлена як сукупність двох компонентів - творчого та особистісного; це частина правової культури суспільства; правову культуру особистості можна розглядати як ступінь і характер їі правового розвитку; правова культура особистості грунтується на позитивній правовій свідомості, що реалізується в активній діяльності; правова культура особистості є основою правової культури фахівця [10, с. 86].

Характеристика поняття «правова культура» за комплексним підходом подана у таблиці 4.

Таблиця 4.Характеристика поняття «правова культура» за комплексним підходом

\begin{tabular}{|l|l|}
\hline В. Потомахін & Правова культура - складова частина загальної культури \\
\hline А. Кармін & $\begin{array}{l}\text { Правова культура - це комплекс цінностей і регулятивів, на основі } \\
\text { яких у всіх сферах життя, які підпадають під норми права, будується } \\
\text { практика взаємин і дій людей, а також різного роду організацій }\end{array}$ \\
\hline В. Велигон & $\begin{array}{l}\text { Правова культура - частина культури суспільства, що відноситься до } \\
\text { сфери дії права і відображена в свідомості, поведінці і в результатах } \\
\text { діяльності людей }\end{array}$ \\
\hline Р. Сербин & $\begin{array}{l}\text { Правова культура є не лише знанням, а й станом волі, } \\
\text { правосвідомості та поведінки громадян, що формується в } \\
\text { демократичному суспільстві під впливом розвитку ринкових } \\
\text { відносин, має гуманістичний характер і грунтується на природному } \\
\text { праві, визначальній ролі прав людини }\end{array}$ \\
\hline О. Скакун & $\begin{array}{l}\text { Правова культура тісно пов'язана з загальною культурою народу, } \\
\text { грунтуться на їі засадах, служить відображенням рівня ії розвитку. } \\
\text { Формування правової культури не є відокремленим процесом від } \\
\text { розвитку інших видів культури -політичної, моральної, естетичної }\end{array}$ \\
\hline I. Шаравара & $\begin{array}{l}\text { Правова культура складається з цілої низки елементів, це: } \\
\text { досягнення якісного стану юридичної охорони та захисту основних } \\
\text { прав і свобод людини і громадянина; ступінь впровадження в } \\
\text { практику суспільного та державного життя принципів верховенства } \\
\text { права і правового закону; рівень правосвідомості громадян та } \\
\text { посадових осіб. }\end{array}$ \\
\hline
\end{tabular}

3 точки зору комплексного підходу правова культура пов'язана 3 політичною, моральною, естетичною, економічної культурою та іншими їі різновидами. Політична культура $\epsilon$ носієм політичних переконань особистості. Простежується взаємозв'язок правової культури і культури моральної. Це обумовлено підвищенням ролі окремої людини, ролі особистості в процесі становлення правової держави і громадянського суспільства. Будь-яка участь людини у правоохоронній або правотворчій діяльності має моральний аспект, i моральні якості особистості впливають на правове життя суспільства і ефективність виконання правових норм. Естетична культура свідчить про ступінь прояву естетичного і емоційного в правовому житті суспільства. Естетична культура базується на міжособистісних відносинах, даючи ціннісну орієнтацію життєдіяльності людини в соціумі. Існує взаємозв'язок правової та економічної культури, оскільки регулююча функція правової культури має велике значення для вдосконалення економічних відносин в суспільстві.

Висновки. Проведений аналіз філософської, історико-педагогічної, юридичної літератури, дозволяє нам зробити висновки, що правова культура - це явище багатоаспектне, яке розглядаємо на основі підходів (аксіологічний, компетентнісний, діяльнісний, комплексний). 3 позицій аксіологічного підходу науковці розглядають правову культуру як якісний рівень правової дійсності на конкретному етапі розвитку суспільства. Аналіз правової культури через правову 
компетентність показує, що вона є ознакою правової культури (між правовою культурою та правовою компетентністю існує діалектичний зв'язок, оскільки відсутність правової культури робить неможливим розвиток правової компетентності; а правова культура є основою для правової компетентності). Представники діяльнісного підходу дотримуються точки зору, згідно 3 якою правова культура визначається як вид i спосіб діяльності, спосіб мислення, норми i стандарти поведінки, специфічний спосіб організації і розвитку людської життєдіяльності в сфері правових відносин, якісний стан правового життя суспільства, виражений в рівні правосвідомості, вдосконаленні правових актів та юридичної практики і в інших правових цінностях. 3 точки зору комплексного підходу правова культура пов'язана 3 політичною, моральною, естетичною, економічної культурою та іншими їі різновидами.

\section{ЛІТЕРАТУРА}

1. Аграновская Е. В. Правовая культура и обеспечение прав личности: монография. Москва: Наука, 1988. 142 c.

2. Андрусишин Р. М. Правове виховання працівників ОВС: теоретико-правовий вимір: дис. ... канд. юрид. наук. Львів, 2016. 226 с.

3. Галущак I. Шляхи формування правової компетентності майбутніх економістів в умовах гірського регіону. Гірська школа Украӥнських Карпат. 2016. № 15. С. 102-105.

4. Комарова О. Ю. Правовая культура как объективная необходимость формирования правового сознания человека в условиях становления гражданского общества: дисс. ... канд. социол. наук. Ярославль, 1998. 268 с.

5. Кравченко И. А., Бастен А. В. Правовая культура участников финансовых правоотношений. Вопросы российского и международного права. 2016. № 9. С. 127-136.

6. Курносенко А. А. Интернет в процессе формирования правовой культуры молодежи в условиях трансформирующегося российского общества: дисс. ... канд. социол. наук. Краснодар, 2016. 172 с.

7. Лемак В. В. Загальна теорія держави і права. Ужгород: ПП «Медіум», 2003. 251 с.

8. Линейцева К. С. Структура правовой культуры и влияние формирования институтов гражданского общества на ее развитие. Правовая инициатива. 2013. № 6. URL: http://49e.ru/ru/2013/6/13 (дата обращения: 18.07.2018).

9. 157, с.3]. Лукаш О. Л. Формування правової культури студентів у трансформаційному суспільстві: автореф. дис. ... канд. юрид. наук. Київ, 2011. 19 с.

10. Мальона С. Б. Правова культура менеджера туризму в процесі професійної підготовки у вузі. Вісник Луганського національного університету ім. Тараса Шевченка. Серія: Педагогічні науки. 2013. № 18, Ч. III. С. 86-91.

11. І. Огороднійчук [23]) Огороднийчук И. А. Диагностика уровней правовой компетентности. Науковий вісник Південноукраӥнського державного педагогічного університету ім. К. Д. Уиинського. Серія: Педагогічні науки. 2008. № 1. С. 225-228.

12. Потомахин В.В. Формирование правовой культуры студентов неюридического профиля подготовки: дисс. ... канд. пед. наук. Курск, 2009. 261 с.

13. Сербин Р. А. Правова культура - важливий фактор розбудови правової держави: дис. ... канд. юрид. наук. Київ, 2003. 185 с.

14. Скакун О. Ф. Теорія держави і права: підручник. Харків: Консум, 2009. 656 с.

15. Правовая культура: метод. пособ. / сост. А. Н. Халтурин. Архангельск: Северный (Арктический) федеральный университет, 2010. 50 с.

16. Циганій С. О. Формування культури професійно-правового спілкування в майбутніх юристів у процесі фахової підготовки: дис. ... канд. пед. наук. Київ, 2017. 239 с.

17. Чернета С., Дурманенко О. Формування правової культури студентської молоді: соціальнопедагогічний аспект. Вісник Чернігівського національного педагогічного університету ім. Т. Г. Шевченка. 2012. Вип. 104, Т. 2. С. 173-176. 